\title{
An Exploratory Paper on Strategy Implementation: Industry Look at Some of the World's Most Profitable and Most Innovative Companies
}

\author{
Hanan A. Alhaddi ${ }^{1}$ \\ ${ }^{1}$ Department of Management and Information System, Ilitch School of Business, Wayne State University, MI, USA \\ Correspondence: Hanan A. Alhaddi, Wayne State University, Prentis Building, 5201 Cass Ave. Detroit, MI 48127, \\ USA.
}

Received: August 16, 2016

Accepted: September 10, 2016

Online Published: October 28, 2016

doi:10.5430/jms.v7n4p1

URL: http://dx.doi.org/10.5430/jms.v7n4p1

\begin{abstract}
We could have a great debate about which concepts, theories, or frameworks are the most effective when it gets to achieving profitable growth, particularly as it pertains to innovation. Despite the fact that some of these concepts and theories are more prominent than others, several have been proven to be effective when implemented by real organizations. This raises several questions regarding the selection criteria and the dynamics among these strategic frameworks. The purpose of this exploratory paper is to shed some light on the different strategy implementations at some of the most profitable and innovative organizations in the world. The high-level and practice-based research has revealed that successful organizations have formulated and executed different strategies and did not limit themselves to a single approach. In fact, some organizations have implemented several strategies simultaneously. The observed multi-strategy formulation and implementation suggests that strategic concepts, theories, and frameworks could be complementary in nature. While this paper is not intended to serve as a literature review, the findings were insightful in terms of the realization of multi-strategy implementation in organizations as well as directing new research to focus on the dynamics among different strategies.
\end{abstract}

Keywords: strategy, innovation, blue ocean strategy, strategic innovation, disruptive innovation

\section{Introduction}

Many conceptual frameworks and theoretical models have been developed with focus on business growth. For example, in management, Drucker introduced decentralization and simplification (Drucker, 1946); in marketing, Levitt discussed Marketing Myopia (Levitt, 1960), while Kotler popularized McCarthy's 1964 concept of the 4Ps marketing mix (Kotler, 2000; McCarthy, 1964); in innovation, Markides suggested that strategic innovation was behind many success stories of market penetration (Markides, 1997) and Christensen coined the term disruptive innovation to describe a type of innovation that creates a new market and value network (Christensen, 1997); in strategy, Porter developed the five forces to analyze competition (Porter, 2008), while Kim and Mauborgne preferred to exist the competition entirely in order to achieve profitable growth by implementing blue ocean strategy-BOS, (Kim \& Mauborgne, 2000).

While these different concepts were developed to ultimately achieve profitable growth, the consensus on the basics of business growth is that a business can either grow through diversification (new product/new market), market development (existing product/new market), product development (new product/existing market), and/or market penetration (existing product/existing market); also known as Ansoff's Matrix (Ansoff, 1957). Interestingly, a mapping of the most prominent concepts and models for business growth reveals that they all funnel into those four areas, independently or jointly (see diagram 1). 


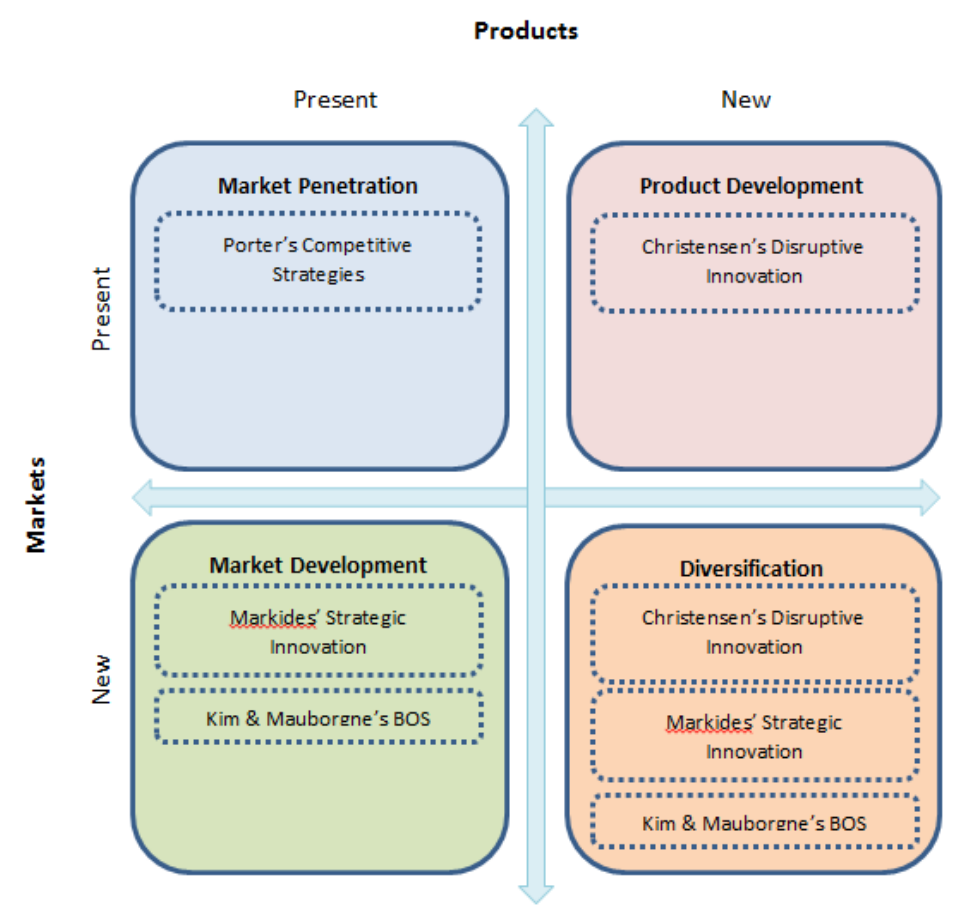

Diagram 1. Placement of strategic frameworks

For example, the work of Markides, Christensen, and Kim \& Mauborgne on strategic innovation, disruptive innovation, and BOS respectively can be viewed through the diversification lens. Similarly, Porter's five forces can be viewed through market penetration lens. In some instances, these concepts overlap and reappear in other growth categories (ex, disruptive innovation can be related to product development and diversification). Because development of markets and products would most likely require an innovative approach, a special emphasis was placed on innovation in this paper. The overlap and reemergence of these concepts on Ansoff's Matrix trigged the following question: if these different yet overlapping frameworks are designed to stimulate profitable growth, do organizations tend to execute a single or multiple strategies in their pursuit for profitable growth? In an attempt to answer this question, a comparative analysis was used to gain some insight into business growth at some of the world's most profitable and innovative organizations.

\subsection{Notes on Research and Data Analysis}

The objective of this practice-based research was to understand strategy deployment and strategic enablers that contributed to the success of several powerful organizations. To this extent, financial data and product information were reviewed with emphasis on iconic products/services. This exploratory paper is not intended to serve as a literature review. This work is an introductory and industry-based look in order to shed some light on what strategies were implemented resulting in profitable growth for organizations. In addition to the annual and financial statements of the selected companies, data on growth, competitive analysis, and innovation were also obtained from lists published by Statisa, Forbes, and Boston Consulting Group-BCG. These sources were selected because of their reputable contribution and wide use in the industry as well as the appropriateness of the computation methodologies used to generate the lists (the exclusion of Forbes will be explained later). The selected lists from each source were Statista's "50 Most Profitable Companies in the World", Forbes" "Most Innovative Companies in the World", and BCG's "50 Most Innovative Companies in 2014". Firstly, the analysis started with Statista's published list of the world's leading companies-by profit. Originally, the list included 50 organizations, for simplicity, the top 15 organizations were included in the analysis. Secondly, since the lists from Forbes and BCG were focused on innovation, they were cross-referenced for consistency. Table 1 below shows a summary of the lists and the methodologies used to compute the ranks. 
Table 1. Reviewed lists

\begin{tabular}{|c|c|c|c|}
\hline Name of List & Publisher & Year & Computation Methodology \\
\hline $\begin{array}{l}\text { Most Innovative Companies } \\
\text { in the World }\end{array}$ & Forbes & 2015 & $\begin{array}{l}\text { Ranked according to the bonus given by equity } \\
\text { investors based on the educated hunch that the } \\
\text { company will continue to come up with profitable new } \\
\text { growth. }\end{array}$ \\
\hline $\begin{array}{l}50 \text { Most Innovative } \\
\text { Companies of } 2014 \text { (most } \\
\text { recent to date) }\end{array}$ & BCG & 2014 & $\begin{array}{l}\text { Ranked according to global innovation survey results } \\
\text { administered to executives on their thoughts of } \\
\text { innovation in their organizations. }\end{array}$ \\
\hline $\begin{array}{l}50 \text { Most Profitable } \\
\text { Companies in the World, } \\
2015\end{array}$ & Statista & 2015 & Ranked according to profits made in fiscal year 2015. \\
\hline
\end{tabular}

Surprisingly, when the Forbes and the BCG lists were cross-referenced, only 6 companies appeared on both. Those included Tesla Motors, salesforce.com, Unilever, Amazon, Fast Retailing, and Starbucks. This observation (in addition to a number of well-known organizations in the innovation domain like Apple and Google not appearing on the Forbes list) raised a question about the rationale behind the ranking computations of the Forbes list. Further analysis revealed that the innovation ranking used to generate the list was done according to an educated hunch that companies will continue to come up with profitable new growth. Because the results shown on the Forbes list seemed subjective, the research continued with data from BCG and Statista. Among the industries included in the analysis was telecommunication, banking \& financial services, oil \& energy, automotive, and technology.

\section{Profitability}

In terms of profitability, Statista's "50 Most Profitable Companies in the World" revealed that more than 50\% of the \$864B profit generated for 2015 was made by the top 15 companies. Further research revealed that the predominant sources of profitable growth in those companies varied; each company was profitable differently. In other words, companies' means of profitability varied from product development to diversification as can be seen from Table 2 .

Table 2. Top 15 most profitable companies in the world

\section{Company Profit (\$B) Predominant means of Growth/Profitability}

\begin{tabular}{|c|c|c|c|}
\hline Vodafone Group & $\$$ & $98.86^{*}$ & $\begin{array}{l}\text { Market development, rapid global expansion in emerging markets, } \\
\text { organically funded acquisitions, focus on one industry (mobile phone) }\end{array}$ \\
\hline $\begin{array}{l}\text { Industrial \& } \\
\text { Commercial Bank of } \\
\text { China }\end{array}$ & $\$$ & 44.44 & $\begin{array}{l}\text { Product development, advantages from government policy changes, } \\
\text { operational efficiencies, innovated processes }\end{array}$ \\
\hline Apple & $\$$ & 39.51 & $\begin{array}{l}\text { Product development, diversification, innovative products and offerings, } \\
\text { customer loyalty, disruptive technological innovation, competitive } \\
\text { strategy }\end{array}$ \\
\hline $\begin{array}{l}\text { China Construction } \\
\text { Bank }\end{array}$ & $\$$ & 36.71 & $\begin{array}{l}\text { Increase in demand for infrastructure loans and online banking, product } \\
\text { development, market development, integrated operation framework, } \\
\text { integrated business model, multifunctional service capability, } \\
\text { operational efficiency }\end{array}$ \\
\hline Exxon Mobil & $\$$ & 32.52 & $\begin{array}{l}\text { Market development, market penetration, integrated business model, } \\
\text { balanced portfolio, global integration of business lines and functional } \\
\text { organizations }\end{array}$ \\
\hline $\begin{array}{l}\text { Agricultural Bank of } \\
\text { China }\end{array}$ & $\$$ & 28.92 & $\begin{array}{l}\text { Increase in demand for large scale loans, integrated operation } \\
\text { framework, integrated business model, advantages from government } \\
\text { policy changes }\end{array}$ \\
\hline Bank of China & $\$$ & 27.33 & Market development, 'Silk Road' innovation, advantages from \\
\hline
\end{tabular}




\begin{tabular}{lccl}
\hline Wells Fargo & $\$$ & 23.06 & $\begin{array}{l}\text { government policy changes } \\
\text { Diversification, technological innovation, customer orientation, } \\
\text { customer loyalty, cross-selling }\end{array}$ \\
\hline Microsoft & $\$$ & 22.07 & $\begin{array}{l}\text { Diversification, innovation, competitive strategy, market development, } \\
\text { market penetration, product development, effective partnerships }\end{array}$ \\
\hline J P Morgan Chase & $\$$ & 21.22 & $\begin{array}{l}\text { Diversification, customer orientation, customer loyalty, cross-selling, } \\
\text { simplification, franchise-base }\end{array}$ \\
\hline Samsung & $\$$ & 21.10 & $\begin{array}{l}\text { Product development, market development, diversification, market } \\
\text { penetration, innovation, late mover advantage, competitive strategy, } \\
\text { expansion beyond market boundaries }\end{array}$ \\
\hline Berkshire Hathaway & $\$$ & 19.87 & $\begin{array}{l}\text { Diversification, balanced portfolio, value investing, acquisitions } \\
\text { Chevron }\end{array}$ \\
\hline China Mobile & $\$$ & 19.24 & $\begin{array}{l}\text { Diversification, innovative technologies, market development, } \\
\text { operational efficiency, focus on cost-efficient reserves, }\end{array}$ \\
\hline Toyota & $\$ 17.71$ & $\begin{array}{l}\text { Market penetration, operational efficiency, late mover advantage } \\
\text { Product development, innovation, operational efficiency (focus on } \\
\text { quality and continuous improvement), customer orientation }\end{array}$ \\
\hline
\end{tabular}

*Figure includes Vodafone's sale of its 45\% stake in Verizon Wireless to Verizon Communications.

Looking at these companies, their sources of profitable growth varied. None has limited their tool kit to one strategy regardless to the industry. For example, Vodafone relied heavily on market development in emerging regions while Wells Fargo diversified heavily pivoting on cross-selling. In the same token, Apple continued to benefit from pioneering the mobile device space while Samsung enjoyed benefits from the late mover advantages in addition to maintaining a balanced portfolio of businesses. Even within the same industry, company's strategies varied. For example, while ExxonMobil prides itself in being barrel-focused, Chevron approaches the oil and gas industry more steadily with focus on cost-efficient reserves. A closer look reveals that many deployed a combination of strategies including competitive strategies, innovation strategies, differentiation strategies, and BOS. Clearly, some have competed, some innovated, some did both, while others did "business as usual". The only common thread among them was that while they seem to have done a variety of things simultaneously, they did it well.

\section{Innovation and Profitability}

BCG's list of most innovative companies was compared to Statista's list of the most profitable companies; 15 companies appeared on both. However, when BCG's list of "Steady Innovators" (a subset of the most innovative list that includes the most innovative companies for the past seven consecutive years) was compared against Statista's list, only 10 companies remained making them the world's most profitable and most innovative companies in the world. Those were: Apple, Google, Samsung, Microsoft, IBM, Toyota, GE, Intel, P\&G, and Walmart. See Table 3.

Table 3. Most steadily innovative \& profitable companies in the world

\begin{tabular}{c}
\hline $\begin{array}{c}\text { Most Steadily Innovative \& Profitable } \\
\text { Companies in the World }\end{array}$ \\
\hline Apple \\
\hline Google \\
\hline Samsung \\
\hline Microsoft \\
\hline IBM \\
\hline Toyota \\
\hline General Electric \\
\hline Intel \\
\hline Proctor \& Gamble \\
\hline Walmart \\
\hline
\end{tabular}


A discussion on innovation can easily take different routes as scholars have developed several conceptual frameworks. For example, there is Christensen's disruptive innovation, Markides' strategic innovation, and Kim \& Mauborgne's value innovation. A question worth asking is what kind of innovation is linked (or associated) to profitability in the case of these 10 companies? Or did these companies execute a multi-approach to innovation? In searching for answers, further analysis was done on the most predominant innovative products/processes of those companies to understand the nature of those innovations. The goal was to examine the type of innovation pursued by those companies with an analytical lens for any patterns.

To this extent, the most innovative products/services were examined against disruptive innovation, strategic innovation, and value innovation. In cases where there is sufficient data that supports the execution of a particular innovation type, explanation was provided. In some instances where no sufficient data was found, this was indicated on the table using "no sufficient evidence/data found". For example, when examining Google's search engine as an innovative product, research revealed that the search engine was a disruptive innovation to traditional research libraries and the internet industry. However, no sufficient data was found supporting that Google pursued strategic innovation or value innovation with the search engine. As the examination continued, it was intriguing to learn that most companies had an overlap of more than one innovation type. In fact, the overlap of different innovations was the common theme in the findings. The compiled list (shown in Table 4) is by no means intended to be comprehensive; it was only developed to shed some light on some of the existing overlaps.

For example, Apple's most known innovations can be divided into 3 groups: tech devices (iPad, iPod, iPhone, MacBook Air, and iTunes), the business model, and the user interface (although this is integrated in the first two). Among all three groups, all three types of innovations were present. In developing and manufacturing the tech devices, Apple has disrupted the digital music industry with iTunes, strategically innovated their products by redefining their business model as a developer of user interface (versus, for example being a tech gadget maker), and created blue oceans pivoting on value innovation by looking across multiple industries (for example, music and technology).

Table 4. Strategy implementation at the 10 most profitable \& innovative companies in the world

\begin{tabular}{|c|c|c|c|c|}
\hline Company & Product/process & Disruptive Innovation & Strategic Innovation & Value Innovation-BOS \\
\hline \multirow[t]{3}{*}{ Apple } & $\begin{array}{l}\text { iPad, iPod, iPhone, } \\
\text { MacBook Air, } \\
\text { iTunes) }\end{array}$ & $\begin{array}{l}\text { Disrupted the digital } \\
\text { music and tech } \\
\text { industries. }\end{array}$ & $\begin{array}{l}\text { Apple identified gaps in the } \\
\text { strategic positioning maps of } \\
\text { multiple industries and decided to } \\
\text { fill them before anyone else. } \\
\text { Apple changed the rules of the } \\
\text { game. }\end{array}$ & $\begin{array}{l}\text { Looked across alternative } \\
\text { industries and strategic } \\
\text { groups with industries to } \\
\text { deliver a valuable product } \\
\text { to customers. }\end{array}$ \\
\hline & Business model & $\begin{array}{l}\text { no sufficient } \\
\text { evidence/data found }\end{array}$ & $\begin{array}{l}\text { Apple redefined the business by } \\
\text { altering the mental model of the } \\
\text { company. Apple no longer was a } \\
\text { manufacturer of computers but a } \\
\text { developer of user interface. }\end{array}$ & $\begin{array}{l}\text { Integrated multiple } \\
\text { industries into the model }\end{array}$ \\
\hline & User interface & $\begin{array}{l}\text { no sufficient } \\
\text { evidence/data found }\end{array}$ & $\begin{array}{l}\text { The newly redefined business } \\
\text { model as a developer of seamless } \\
\text { user interface enabled Apple to } \\
\text { change the rules of the } \\
\text { technological gadgets game. }\end{array}$ & $\begin{array}{l}\text { innovated value in user } \\
\text { interface by providing } \\
\text { simple, intuitive, and } \\
\text { friendly processes to } \\
\text { customers through } \\
\text { multiple devices. }\end{array}$ \\
\hline \multirow[t]{2}{*}{ Google } & Search engine & $\begin{array}{lr}\text { Disrupted research } \\
\text { libraries and the } \\
\text { internet industry (other } \\
\text { competing search } \\
\text { engines), and printed } \\
\begin{array}{l}\text { directory (Yellow } \\
\text { Pages). }\end{array}\end{array}$ & no sufficient evidence found & $\begin{array}{l}\text { no sufficient } \\
\text { evidence/data found }\end{array}$ \\
\hline & Gmail & $\begin{array}{l}\text { no sufficient evidence } \\
\text { found }\end{array}$ & $\begin{array}{l}\text { Google identified gaps in the } \\
\text { strategic positioning map of the }\end{array}$ & $\begin{array}{l}\text { no sufficient } \\
\text { evidence/data found }\end{array}$ \\
\hline
\end{tabular}


internet industry with respect to electronic mail. Gmail was developed to fill the need gap for more email functionality, storage and search.

\begin{tabular}{lll}
\hline Google Earth & $\begin{array}{l}\text { no } \\
\text { evidence/data found }\end{array}$ & $\begin{array}{l}\text { sufficient } \\
\text { no sufficient evidence/data found }\end{array}$
\end{tabular}

\begin{tabular}{ll}
\hline AdSense & Disrupted traditional \\
& marketing and retail \\
& industries by allowing \\
& advertisers to reach \\
& their target audience t \\
& more precisely via the to \\
& internet \\
\hline Android OS & Disrupted the mobile \\
& handset industry
\end{tabular}

Google identified gaps in the strategic positioning map of the digital marketing industry. It developed AdSense with technologies to enable advertisers to reach target audience more precisely. Disrupted the mobile no sufficient evidence/data found

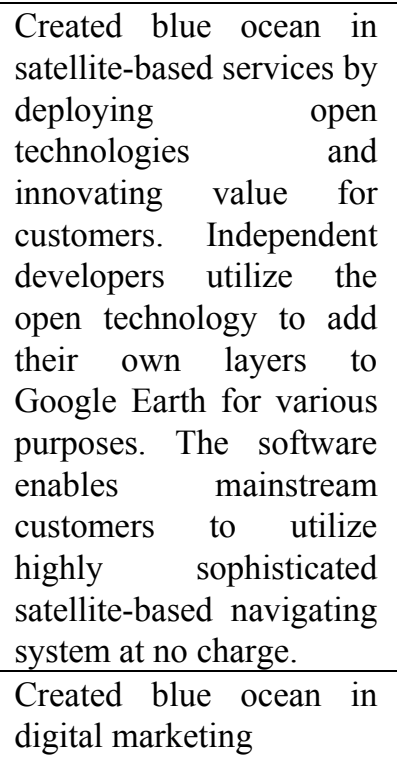

Created blue ocean in mobile platforms by deploying open technology. Today, over 310 devices on built on Android OS

Innovated value for customers by combining all the features of high end GPS in addition to seamlessly integrating the customer's mobile features (like contact list, preferred locations, etc.) to offer a highly personalized customer experience.

\begin{tabular}{|c|c|c|c|c|}
\hline Samsung & $\begin{array}{l}\text { TRIZ } \\
\text { (problem-solving } \\
\text { methodology to } \\
\text { approach for } \\
\text { invention-related } \\
\text { tasks). }\end{array}$ & $\begin{array}{l}\text { Although TRIZ did not } \\
\text { disrupt other } \\
\text { technologies, it is a } \\
\text { powerful tool to } \\
\text { leverage disruptive } \\
\text { innovation by adopting } \\
\text { a systematic approach } \\
\text { to innovation. }\end{array}$ & no sufficient evidence/data found & $\begin{array}{l}\text { TRIZ methodology is an } \\
\text { enabling tool to create } \\
\text { blue oceans of product } \\
\text { innovations. }\end{array}$ \\
\hline
\end{tabular}


evidence/data found

functional appeal of the customer to offer an innovative feature that enables the user to access certain features of the phone without unlocking the screen.

OLED Curved TV no sufficient Samsung redefined its business Looked across the
evidence/data found model by being the first to functional and emotional identify a new customer want (an appeal of the customer to organic and eye-friendly screen shape for optimum viewing environment) offer an organic and eye-friendly shape of the curved display. The degree of curvature of the display contributes to an optimum viewing environment.

Built-in heart rate no sufficient no sufficient evidence/data found
Looked across functional monitor in Galaxy evidence/data found S5 and emotional appeal of customers to provide a practical feature that helps customers in improving their life.

\begin{tabular}{|c|c|c|c|c|}
\hline \multirow[t]{3}{*}{ Microsoft } & Encarta & $\begin{array}{l}\text { Disrupted academia by } \\
\text { offering professionally } \\
\text { edited digital } \\
\text { encyclopedias }\end{array}$ & no sufficient evidence/data found & $\begin{array}{l}\text { no sufficient } \\
\text { evidence/data found }\end{array}$ \\
\hline & Microsoft DOS & $\begin{array}{l}\text { Disrupted the computer } \\
\text { industry by introducing } \\
\text { the } 16 \text {-bit OS for } \\
\text { personal computers }\end{array}$ & no sufficient evidence/data found & $\begin{array}{l}\text { Created blue ocean in } \\
\text { personal computer } \\
\text { operating systems }\end{array}$ \\
\hline & Windows & $\begin{array}{l}\text { The original operating } \\
\text { system grew } \\
\text { inadequate to those of } \\
\text { minicomputers and } \\
\text { mainframe (ex, Unix); } \\
\text { its migration to } \\
\text { Windows (from DOS) } \\
\text { shaped the computer } \\
\text { industry }\end{array}$ & no sufficient evidence/data found & $\begin{array}{l}\text { Created blue ocean in } \\
\text { personal computer } \\
\text { operating systems }\end{array}$ \\
\hline
\end{tabular}

\begin{tabular}{|c|c|c|c|c|}
\hline IBM & Personal Computers & $\begin{array}{l}\text { Disrupted computers } \\
\text { and typewriter industry }\end{array}$ & $\begin{array}{l}\text { IBM redefined its business as a } \\
\text { provider of mainframe computers }\end{array}$ & $\begin{array}{l}\text { Created blue ocean in } \\
\text { personal computers }\end{array}$ \\
\hline & Watson & $\begin{array}{l}\text { Disrupted } \\
\text { industry by providing } \\
\text { artificial } \\
\text { intelligence-based } \\
\text { computer system that is } \\
\text { able to process } \\
\text { information }\end{array}$ & no sufficient evidence/data found & $\begin{array}{l}\text { Created blue ocean by } \\
\text { looking across multiple } \\
\text { industries (technology } \\
\text { and health) to provide a } \\
\text { computer system that is } \\
\text { willing to provide } \\
\text { health-related answers. }\end{array}$ \\
\hline
\end{tabular}

provide management decision 


\begin{tabular}{|c|c|c|c|c|}
\hline \multirow[t]{3}{*}{ Toyota } & Small/reliable cars & $\begin{array}{l}\text { Disrupted the } \\
\text { automotive industry } \\
\text { (especially the big } 3 \\
\text { market) by offering } \\
\text { smaller, lighter, and } \\
\text { more reliable cars. } \\
\text { Toyota entered the US } \\
\text { market with small } \\
\text { volumes but now it is } \\
\text { competing against the } \\
\text { big 3 with vehicle } \\
\text { classes ranging from } \\
\text { economy to luxury. }\end{array}$ & no sufficient evidence/data found & $\begin{array}{l}\text { no sufficient } \\
\text { evidence/data found }\end{array}$ \\
\hline & Prius & $\begin{array}{l}\text { no sufficient } \\
\text { evidence/data found }\end{array}$ & $\begin{array}{l}\text { Toyota redefined its business } \\
\text { model to become an integrator of } \\
\text { gas and electric-based engines. }\end{array}$ & $\begin{array}{l}\text { Created blue ocean in the } \\
\text { hybrid vehicle market by } \\
\text { looking across multiple } \\
\text { industries (energy and } \\
\text { automotive). The } \\
\text { company pioneered the } \\
\text { concept of alternative } \\
\text { fuel cars. }\end{array}$ \\
\hline & Kaizen & $\begin{array}{l}\text { Disrupted multitude of } \\
\text { industries as a } \\
\text { continuous } \\
\text { improvement } \\
\text { methodology. } \\
\text { Developed by Toyota, } \\
\text { other OEMs didn't } \\
\text { grant it much attention. } \\
\text { As the benefits of } \\
\text { Kaizen unfolded in cost } \\
\text { reduction and quality } \\
\text { improvement, the } \\
\text { methodology moved up } \\
\text { in the market shaping } \\
\text { the automotive industry } \\
\text { as competitors strive to } \\
\text { outperform Toyota. }\end{array}$ & no sufficient evidence/data found & $\begin{array}{l}\text { no sufficient } \\
\text { evidence/data found }\end{array}$ \\
\hline GE & $\begin{array}{lr}\text { MAC400 and } \\
\text { MACi (low cost } \\
\text { ECG machines) }\end{array}$ & $\begin{array}{l}\text { Originally developed } \\
\text { by GE as a low-cost } \\
\text { ECG alternative for its } \\
\text { emerging markets in } \\
\text { China and India. } \\
\text { Significant growth of } \\
\text { both products drove GE } \\
\text { to invest } \$ 6 \mathrm{~B} \text { in order } \\
\text { to implement the } \\
\text { design for developed } \\
\text { markets through the } \\
\text { Healthmagination } \\
\text { Initiative in } 2009 \text {. }\end{array}$ & no sufficient evidence/data found & $\begin{array}{l}\text { Created blue ocean in } \\
\text { uncontested market space } \\
\text { in developing regions. }\end{array}$ \\
\hline Intel & Microprocessors & $\begin{array}{l}\text { Fundamentally altered } \\
\text { the structure of the } \\
\text { personal computer } \\
\text { industry despite the }\end{array}$ & no sufficient evidence/data found & $\begin{array}{l}\text { no sufficient } \\
\text { evidence/data found }\end{array}$ \\
\hline
\end{tabular}




\begin{tabular}{|c|c|c|c|c|}
\hline & & humble beginnings. & & \\
\hline$P \& G$ & Crest Whitestrips & $\begin{array}{l}\text { Disrupted the dental } \\
\text { health industry to } \\
\text { targeting noncustomers } \\
\text { through offering a } \\
\text { low-cost } \\
\text { teeth-whitening product } \\
\text { that historically has } \\
\text { been offered by dentists } \\
\text { at a much higher cost. }\end{array}$ & $\begin{array}{l}\text { P\&G redefined its business model } \\
\text { by focusing on a new segment of } \\
\text { customers (those who are } \\
\text { interested in in-home teeth } \\
\text { whitening) as the right customer } \\
\text { for the Crest Whitestrips product. }\end{array}$ & $\begin{array}{l}\text { Created blue ocean by } \\
\text { looking across industries } \\
\text { (dental and personal } \\
\text { hygiene) to provide a } \\
\text { cost-effective product for } \\
\text { teeth-whitening. }\end{array}$ \\
\hline Wal-Mart & Business model & $\begin{array}{l}\text { Disrupted the retail } \\
\text { industry starting with a } \\
\text { single store based on } \\
\text { offering more for less } \\
\text { strategy. }\end{array}$ & no sufficient evidence/data found & $\begin{array}{l}\text { Created blue ocean in } \\
\text { large discount retail by } \\
\text { offering the lowest cost } \\
\text { for products in } \\
\text { good-sized stores }\end{array}$ \\
\hline
\end{tabular}

As mentioned earlier, Google disrupted the library and the internet industry with the search engine, strategically innovated email (with Gmail), and created uncontested space with its Android OS; a deployment of open technology enabling hundreds of various devices in multiple industries to operate on Android. With AdSense alone, all three innovations are demonstrated. The software 1) has disrupted the traditional marketing industry, 2) was strategically innovated by identifying gaps in the strategic positioning map of the digital marketing industry and the development of technologies that enable advertisers to reach target audience more precisely, and 3) was a source of value innovation to digital marketers creating by that uncontested space in online advertisement.

Samsung is another example were research revealed unconventional ways of demonstrating the different types of innovations. For example, although Samsung's innovations do not seem - at first glance - to have disrupted any industries, TRIZ (a problem-solving, analytical, and forecasting methodology for invention-related tasks) is essentially an enabling tool of disruptive innovation. Developed by Samsung, the TRIZ methodology enables innovators to predict trends in product innovation. Similarly, TRIZ is an enabling tool for the creation of blue oceans as it facilitates the process of product innovation and hence, tapping into uncontested market space. Further, the OLED Curved TV was strategically innovated as Samsung redefined its business by being the first to identify a new customer want (an organic and eye-friendly screen shape for optimum viewing environment). Finally, Galaxy S6 Edge is a demonstration of value innovation as the company looked across the functional and emotional appeal of customers by providing a practical and eye-friendly feature that enables them to access phone features without unlocking the home screen. The list also shows Microsoft's Ecarta, DOS, and Windows; IBM's personal computers and Watson; Toyota's small cars, Prius, and Kaizen; GE's MAC400 and MACi; Intel's microprocessors, P\&G's Crest Whitestrips; Wal-Mart business model.

\section{Concluding Remarks}

In short, different companies across multitude of industries formulated and executed different strategies and innovation disciplines. Even within the same industry, companies implemented different concepts and frameworks. What is important is that these concepts and theories are not competing against one another; the business world is far more multifaceted for one size to fit all (Fox, 2013). Barriers to entry, market conditions, state of economy, consumer trends, maturity of industries, and organizational structures among other factors increase the complexity of the business environment. In that respect, should companies compete all the time? Should they innovate all the time? Or should they develop markets all the time? The answer probably to all of these questions is no. So what is the best strategy to grow the business? What is the best way to play the growth game? In reality, the answer that no business manager wants to hear is: do what works for the organization. But we know it has to be done different than other players (Porter). Organizations have options; they can change the rules of the game (Markides) or disrupt the game (Christensen). However, with time, other players in the market will be in a position to fiercely compete, the organization can then choose to exit the game and play a different one elsewhere (Kim \& Mauborgne). In light of that, direction for new research should focus on examining the dynamics among the different strategic and innovation frameworks. The objective of the research should be to examine any conditions that would cause a company to select one strategy over the other or pursue a multi-strategy approach. It is also recommended that new research explores any preferred sequences for strategy formulation and implementation. 


\section{References}

Ansoff, I. (1957). Strategies for diversification. Harvard Business Review, 113-124.

BCG. (2015). The most innovative companies: an interactive guide. Retrieved 10/3/2015 from https://www.bcgperspectives.com/content/interactive/innovation_growth_most_innovative_companies_interacti ve_guide/

Christensen, C. (1997). The Innovator's Dilemma. Boston: Harvard Business Review Press.

Drucker, P. (1947). Concept of the Corporation. New York: The John Day Company.

Forbes. (2015). The world's most innovative companies. Retrieved 10/1/2015 from http://www.forbes.com/innovative-companies/list/

Fox, J. (2013, January 29). Apple versus the strategy professors. Harvard Business Review. Retrieved 10/11/2015 from https:/hbr.org/2013/01/apple-versus-the-strategy-prof.html

Kim, W., \& Mauborgne, R. (2005). Blue Ocean Strategy. Boston: Harvard Business School Press.

Kotler, P. (2000). Marketing Management. London: Prentice-Hall International.

Levitt, T. (1960). Marketing Myopia. Harvard Business Review, 45-56.

Markides, C. (1997). Strategic innovation. Sloan Management Review, 9-23.

McCarthy, J. E. (1964). Basic marketing: A managerial approach. Homewood, IL: Irwin.

Microsoft. (2015). Microsoft annual report. Retrieved 11/7/2015 from https://www.microsoft.com/investor/reports/ar15/index.html

Porter, M. (2008). The five competitive forces that shape strategy. Harvard Business Review, 86-104.

Smith, A. (1776). Wealth of Nations. New York: Oxford University Press. (Original work published in 1776).

Statista. (2015). The leading companies in the world in 2015, by profit (in billion U.S. dollars). Retrieved 10/2/2015 from http://www.statista.com/statistics/269857/most-profitable-companies-worldwide/ 